\title{
Seroprevalence of Hepatitis B and Hepatitis C in Rural Areas of Düzce Province After an Earthquake*
}

\author{
Deprem Sonrası Düzce Ili Kırsalında Hepatit B ve Hepatit C Seroprevalansı
}

Mehmet Faruk Geyik, Nevin İnce'1, Davut Özdemir' ${ }^{1}$, Hayriye Ak Yıldırım²

'Düzce Üniversitesi Tıp Fakültesi, Enfeksiyon Hastalıları ve Klinik Mikrobiyoloii Anabilim Dalı Düzce

2Düzce Üniversitesi Tıp Fakültesi, Biyokimya Anabilim Dalı, Düzce

* Bu makale Poster-bildiri olarak 2.Ulusal Klinik Mikrobiyoloji Kongresinde PS386 numara ile sunulmustur.
Received : 18.09.2014• Accepted: 17.11.2014

\section{Corresponding Author}

Yrd.Doç.Dr.Nevin INCE

Aim: Increases in the incidences of various infectious diseases have been reported after natural disasters such as earthquakes. This study was conducted to investigate whether the seroprevalence of hepatitis B and hepatitis C, which can be transmitted horizontally or through blood, increased after the Düzce earthquake due to unfavorable changes in environmental conditions, as well as injuries, and crowded living.

Materials and Methods: Blood samples were obtained from a total of 2296 residents of rural Yığılca in Düzce province.. After separating the serum, samples were evaluated for HBsAg and anti-HCV seropositivity using Equipar ELISA kits (üretici firma/ülke).

Results: Of the 2296 people included, $64 \%$ were female $(n=1471)$ and $36 \%$ were male $(n=$ $825)$. The mean age of the patients was 49.7 ( $\pm 14: 2$ ) years. HBsAg positivity was detected in 42 people (1.8\%), and anti-HCV positivity was detected in eight people $(0.3 \%)$.

Conclusion: The results of this study showed that hepatitis B and hepatitis $C$ seroprevalence rates were not higher than the average values for Turkey as anticipated. Yığılca region sustained moderate earthquake damage, has low population mobility due to limited immigration to the region, and is a closed society, all factors which could explain the average seroprevalence rates.

Key Words: Earthquake, Seroprevalence hepatitis, Düzce

Amaç: Deprem gibi doğal afetler sonrasında çeșitli enfeksiyon hastalıklarının görülme sıklığında artıș bildirilmiștir. Bu çalıșma, Düzce depreminden sonra çevre șartlarındaki olumsuz değișimle birlikte, yaralanmalar ve kalabalık yașam sonrasında kan yoluyla veya horizontal olarak bulașabilen Hepatit B ve Hepatit C seroprevalansında farklılık olup olmadığının araștırılması amacıyla yapıldı.

Gereç ve Yöntem: Düzce ili Yığılca kırsalında yașayan toplam 2296 kișinin kan örnekleri alındı. Serumları ayrıldıktan sonra örnekler HBsAg ve Anti HCV seropozitifliği açısından Equipar ELISA kitleri (üretici firma/ülke) kullanılarak çalıșıldı.

Bulgular: 2296 kișinin \%64'ü kadın $(n=1471)$ \%36'sı erkek $(n=825)$ idi. Hastaların yaș ortalaması $49,7( \pm 14,2)$ olarak saptandı. HBsAg pozitifliği 42 (\%1,8) kișide, antiHCV pozitifliği sekiz $(\% 0,3)$ kișide tespit edildi

Sonuç: Calıșma sonucunda elde edilen Hepatit B ve Hepatit C seroprevalans oranlarının beklenilenin aksine Türkiye ortalaması verilerinden daha yüksek olmadığı bulundu. Bu durumun Yığılca bölgesinin depremde orta derecede hasar alması, dıșarıdan göç almayıp nüfus hareketliliğinin az olması, kendi içinde kapalı bir toplum olması gibi nedenlerden kaynaklanabileceği düșünüldü.

Anahtar Sözcükler: Deprem, Hepatit Seroprevalansı, Düzce

Sudden natural disasters, such as earthquakes, tsunamis, floods, landslides, and tornados, have widespread effects on communities and are major public health problems, often causing injury and death. Increased incidences of infectious diseases have been identified in residents living in affected areas due to lack of hygiene and sanitation, crowded living conditions, and population movements (1). Vector-mediated infections, including viral and bacterial diarrhea, hepatitis $\mathrm{A}$ and $\mathrm{E}$, pneumonia, malaria, and West Nile 
encephalitis, may occur after an earthquake due to factors such as failure to provide clean water and nutrients, limited number of shelters, and cohabitation in crowded and enclosed places (2). Additionally, emergency surgical operations due to injuries and trauma or blood transfusions may play a role in the spread of blood-borne infections, such as hepatitis B and C (3).

Viral hepatitis is a major health problem widely seen both globally and in our country, and may progress acutely or chronically. While hepatitis A and E are transmitted through the oral-fecal route, hepatitis $\mathrm{B}$ and $\mathrm{C}$ are transmitted parenterally, by sexual contact, and horizontally from person to person in crowded living conditions. Globally, an estimated two billion people have encountered hepatitis B virus (HBV), 400 million people are chronic hepatitis B carriers, and about 150-170 million people have been infected with hepatitis $\mathrm{C}$ virus (HCV) (4). Turkey is among the areas with medium endemicity rates for carriage of HBV. Several studies of different regions have reported $\mathrm{HBsAg}$ positivity rates between $1.3 \%$ and $13.8 \%$ and anti$\mathrm{HCV}$ positivity rates between $1 \%$ and $2.4 \%(5,6)$.
Several published studies have reported an increase in infectious diseases after earthquakes in Turkey and other countries (2, 3, 7, 8). Although studies have examined the surveillance of hepatitis $A$ and $E$ transmitted in the acute stage via the oral-fecal route, no publications have investigated the long-term seroprevalence of parenterally transmitted hepatitis B and C (8). In this study, we investigated hepatitis B and hepatitis $C$ seroprevalence rates in rural Yığılca in Düzce province 10 years after an earthquake in 1999 and compared the rates with the average rates for Turkey.

\section{MATERIALS AND METHODS}

The study was conducted in rural Yiğılca which experienced two major earthquakes in 1999, sustaining moderate damage to many buildings, but was not a highly preferred immigration destination due to its remote location. In June and July of 2010, we visited the region and recruited 2296 adults who volunteered to participate in the study. Written consent was obtained from all participants. Venous blood samples from participants were collected in gel tubes and centrifuged at $3000 \mathrm{rpm}$ for 5 minutes to separate the serum. Serum samples were stored at $-20^{\circ} \mathrm{C}$ until used. The samples were examined with using the Equipar HBsAg single-stage test (Equipar Diagnostici, Saronno (Va), Italy) and the Equipar anti-HCV single-stage test (Equipar Diagnostici, Saronno (Va), Italy). Results were evaluated as positive or negative.

\section{RESULTS}

Of the 2296 participants, 64\% were female ( $\mathrm{n}=1471)$ and $36 \%$ were male $(\mathrm{n}=825)$. The mean age of the participants was $49.7( \pm 14: 21)$ years. Forty-two people $(1.8 \%)$ were positive for $\mathrm{HBsAg}$ and eight $(0.3 \%)$ were positive for HCV (Table 1). Both HBsAg and anti-HCV positivity were observed in one person. When analyzed by gender HBsAg positivity was detected in $1.2 \%$ of women and $2.7 \%$ of men, while anti-HCV positivity was detected in $0.3 \%$ of women and $0.2 \%$ of men. The mean age of the HBsAg-positive patients was 44.2 years compared to 51.6 years for the anti-HCV-positive patients.

\section{Table 1: The results of hepatitis screening in the Yığılca region}

\begin{tabular}{|c|c|c|c|}
\hline & Positivity (n) & Positivity (\%) & Number of people screened (n) \\
\hline HBsAg & 42 & $1.8 \%$ & 2296 \\
\hline Anti-HCV & 8 & $0.3 \%$ & 2296 \\
\hline
\end{tabular}

\section{DISCUSSION}

Natural disasters are events that have serious health, social, and economic consequences. Disasters, such as earthquakes, tsunamis, floods, landslides, and tornados, result in changes to the resident population and the environment that lead to unhygienic and crowded living conditions and inadequate access to health facilities. These changes can facilitate the development and transmission of infectious diseases (1, 2). Various studies have investigated emerging infectious diseases in areas affected by natural disasters and recommended implementing postdisaster risk assessment, rapid planning in health care facilities and disease prevention measures in damaged areas (1, 2). Emergency surgeries and blood transfusions due to crushes, falls, and injuries during an earthquake have been reported as risk factors for blood-borne infectious diseases (3, 9). A study conducted in affected regions after the 2005 earthquake in Pakistan performed anti-HCV and anti-HIV screening after the earthquake and 11 months later; an increase in anti$\mathrm{HCV}$ positivity was detected, although not statistically significant, but anti-HIV positivity was not observed (3).

Hepatitis B virus is transmitted via transfusions of blood and blood products, sexual contact, and horizontally from person-to-person in crowded spaces. Hepatitis C is transmitted similarly to hepatitis B, although hepatitis $C$ transmission occurs more often via the parenteral 
route $(5,6)$. This study aimed to investigate $\mathrm{HBsAg}$ and anti-HCV positivity rates in rural Yığılca ten years after the Düzce earthquake, as well as, the long-term effects of the earthquake and to compare the obtained data with average values in Turkey.

Different results were obtained from hepatitis screenings conducted in various regions of Turkey. A screening of the general public conducted between 1976 and 1997 reported a mean $\mathrm{HBsAg}$ positivity rate of $6.1 \%$ (range $3.5-14.3 \%$ ). Another normal population screening conducted with 277,627 people between 2000 and 2005 reported a HBsAg positivity rate of $7.6 \%$ (10). A meta-analysis by Toy et al., which evaluated 339 studies conducted in Turkey between 1999 and 2009, reported the prevalence of chronic hepatitis B positivity as $4.57 \%$. Toy et al. detected differences between age groups and regions in terms of hepatitis B positivity (11). Seroprevalence studies conducted in the eastern and southeastern regions of Turkey revealed the following hepatitis $\mathrm{B}$ positivity rates: $12.6 \%$ in Batman, $10 \%$ in Siirt, $12.9 \%$ in Sanliurfa, 9.1\% in Erzurum, and $5.1 \%$ in Hakkari. The high seroprevalence rates in these regions might be associated with overcrowding and rapid population

\section{REFERENCES}

1. Watson JT, Gayer M, Connolly MA: Epidemics after natural disasters. Emerg Infect Dis 2007; 13:1-5.

2. Kouadio IK, Aljunid S, Kamigaki T, et al. Infectious diseases following natural disasters: prevention and control measures. Expert Rev Anti Infect Ther 2012; 10:95-104

3. Khan S, Rai MA, Khan A, et al. Prevalence of HCV and HIV infections in 2005Earthquake-affected areas of Pakistan. BMC Infect Dis 2008; 27;8:147. growth, poor education, low socioeconomic conditions, and poor infrastructure (12-16). Contrary to expectation, studies conducted in the western region, which is more developed, have detected high HBsAg positivity rates in provinces with high immigration rates, such as Izmir and Denizli (7\% and 10.6\%, respectively) $(17,18)$. In our study, the detected HBsAg positivity rate in rural Yığılca was low $(1.8 \%)$ compared to rates across the country. In another study, HBsAg positivity rates in Düzce and its districts were as follows: center of Düzce, $4.3 \%$; Akçakoca, 6.7\%; Gölyaka, 6.2\%; Gümüşova, 1.4\%; and Kaynaşlı, 6.8\% (19). Some regions with high $\mathrm{HBs} A g$ positivity are destinations for tourists or immigrants, or contain populations with a history of working in other countries; this may explain the differences in $\mathrm{HBsAg}$ positivity between regions. The $\mathrm{HBsAg}$ positivity rate in rural Yı̆̆llca was lower than the national average as well as the rates for other Düzce districts. The Yığılca region sustained moderate earthquake damage, has a lower rate of trauma cases compared to other regions, experienced limited immigration to the region after the earthquake, and is a closed society, all factors which could explain the low $\mathrm{HBs} A g$ positivity rate.
Blood transfusions that were not screened for hepatitis C, intravascular drug use, and use of medical instruments without appropriate sterilization are known risk factors for hepatitis $\mathrm{C}$ infection. The worldwide prevalence of hepatitis $\mathrm{C}$ is reported as 3\%, studies conducted in various regions of Turkey with risk groups reported mean prevalence rates varying between $1 \%$ and $2.4 \%$ (6). Kaçmaz et al. conducted a study in Ankara in 2003 and reported an anti-HCV positivity rate of $0.5 \%(20)$. Aslan et al. reported slightly a higher anti-HCV positivity rate of $2.6 \%$ in Sanliurfa (21). In the present study, anti-HCV positivity in Yiğılca was detected as $0.3 \%$, which is similar to the seroprevalence rates in Düzce province and in Turkey in general.

In the aftermath of natural disasters, such as earthquakes, the incidence of infectious diseases are known to increase depending on various factors. Contrary to expectation, the $\mathrm{HBsAg}$ and anti-HCV positivity rates in rural Yiğılca ten years after the Düzce earthquake were not found to be higher than Turkey's average in the present study. Yığılca experienced moderate earthquake damage, has low population mobility as it is not an immigration destination, and is a closed society, all of which may explain the unexpectedly low positivity rates.
4. Hepatitis B. World Health Organization. http://www.who.int/mediacentre/factsheets

5. Mistık R. Türkiye'de viral hepatit epidemiyolojisi yayınların irdelenmesi. Ed: Tabak F, Balık İ, Tekeli E, In: Viral Hepatit 2007, İstanbul: 1.Bask1, Viral Hepatitle Savașım Derneği 2007: 10-50.

6. Sünbül M. HCV enfeksiyonlarının epidemiyolojisi ve korunma. Ed: Tabak F, Balık İ, In: Viral Hepatit 2009, İstanbul: 1. Baskı, Viral Hepatitle Savaşım Derneği 2009: 208-219.
7. Vahaboglu H, Gundes S, Karadenizli A, et al. Transient increase in diarrheal diseases after the devastating earthquake in Kocaeli, Turkey: results of an infectious disease surveillance study. Clin Infect Dis 2000;31:1386-1389.

8. Sencan I, Sahin I, Kaya D, et al. Assessment of HAV and HEV seroprevalence in children living in postearthquake camps from Düzce, Turkey. Eur J Epidemiol 2004;19:461-465.

9. Vanholder R, van der Tol A, De Smet M, et al. Earthquakes and crush syndrome casualties: lessons learned from the Kashmir disaster. Kidney Int 2007;71:1723. 
10. Tosun S. Türkiye'de Viral Hepatit B Epidemiyolojisi Yayınların Metaanalizi. Ed: Tabak F, Tosun S, In: Viral Hepatit 2013, İstanbul, 1. Bask1, Viral Hepatitle Savaşım Derneği, 2013: 27-80.

11. Toy M, Önder FO, Wörmann T, et al. Age- and region-specific hepatitis B prevalence in Turkey estimated using generalized linear mixed models: a systematic review. BMC Infec Dis 2011; $11: 337$.

12. Demirpençe Ö, Tezcan SI, Değirmen E, et al. Seroprevalence of HAV, HBV, $\mathrm{HCV}$ and HIV in People Admitted to Batman State Hospital. J Viral Hepat 2012;18:6-10.

13. Tunç N, Eraydın H, Çetinkaya E, et al. HBsAg, Anti-HBs, Anti-HCV and AntiHIV Seroprevalence of the Patients
Apply to Siirt Public Hospital. J Viral Hepat 2011; 17:7-11.

14. Özbilge H, Ulukanlıgil M, Taşçı S, et al. Seroprevalance of Hepatitis B in Different Groups. Journal of Turkish Society of Microbiol 2000;30:46-48.

15. Kaçar F, Erol S, Parlak M, et al. The Seroprevalence of Hepatitis B Virus Infection in Erzurum and its Vicinity. Turkish Journal of Infection 2003;17:389393.

16. Tekay F. Seroprevalances of HBV, HCV and HIV in Hakkari Province. Dicle Medical Journal 2006; 33:170-173.

17. Afşar İ, Güngör S, Özbaş G, ver ark. Atatürk Eğitim ve Araştırma Hastanesi Mikrobiyoloji Laboratuvar1 HBsAg, AntiHCV ve AntiHIV seropozitifliğinin
2003 y1lı değerlendirilmesi. İzmir Atatürk Eğitim Hastanesi Dergisi 2005;43:9-12.

18. Saçar S, Asan A, Toprak S, et al. HBsAg Seroprevalance in a Country in Turkey Where Tobacco Labours are Prevalent. (Letter to Editor). Bulletin of Microbiology 2007; 41:163-164.

19. Çakır S. Düzce İlinde Erişkinlerde Hepatit $B$ ve Hepatit C Seroprevalansı. Uzmanlık Tezi, Düzce: Düzce Üniversitesi Tip Fakültesi, Enfeksiyon Hastalıkları Anabilim Dalı 2009.

20. Kaçmaz B. Seroprevalence of Hepatitis B and Hepatitis $C$ Infections in Ankara City. J Viral Hepat 2003;8:97-101.

21. Aslan G, Ulukanligil M, Seyrek A. Seroprevalance of Hbsag, Anti-Hbs and Anti-Hcv In Sanliurfa . J Viral Hepat 2001;7:408-410. 